\title{
Studies on acid cheese texture by a computerized, constant speed, cone penetrometer
}

\author{
J. KOROLCZUK, M. MAHAUT \\ INRA, Laboratoire de Recherches de Technologie laitière \\ 65, rue de Saint-Brieuc, 35042 Rennes Cedex, France
}

\section{Summary}

A constant speed cone penetrometer (Stevens, Grande-Bretagne) was connected to a microcomputer (Apple II plus, USA) and used to analyse the tangential stress of acid cheese samples as a function of the cone angle $\left(20,30,40,60\right.$ and $\left.90^{\circ}\right)$ and the penetration speed $(0.2,0.5,1.0$ and $2.0 \mathrm{~mm} / \mathrm{s})$.

The studied three types of the market cheese samples, containing $6.6 \%$ to $10.4 \%$ protein and $40 \%$ or $55 \%$ fat/total solids, behaved as a Bingham body. The tangential stress was proportional to the penetration speed and inversely proportional to the cosine of the cone angle.

The intercept value of the tangential stress was between $200 \mathrm{~Pa}$ and $5 \mathrm{kPa}$ for the intact samples and 2 to 5 times less if the texture of the samples was weakened by their transfer from the cheese packing-boxes to a penetrometer's test cup.

Key words : Acid cheese - Texture - Penetrometic method - Tangential stress.

\section{Résumé}

Etude de la texture des fromages frais avec un pénétromètre à cône, à vitesse constante, informatisé

Un pénétromètre à cône, à vitesse constante (Stevens, Grande-Bretagne) était connecté à un microordinateur. Il était utilisé pour analyser la contrainte tangentielle des échantillons de fromages frais en fonction de l'angle du cône $\left(20,30,40,60\right.$ et $\left.90^{\circ}\right)$ et de la vitesse de pénétration $(0,2 ; 0,5: 1,0$ et $2,0 \mathrm{~mm} / \mathrm{s})$.

Trois types de fromages du marché, contenant de $6,6 \%$ à $10,4 \%$ de protéines et de 40 à $55 \%$ de matière grasse/extrait sec, avaient un comportement de corps de Bingham. La contrainte tangentielle était proportionnelle à la vitesse de pénétration et inversement proportionnelle au cosinus de l'angle du cône.

La valeur de l'ordonnée à l'origine de la contrainte tangentielle se situait entre 200 $\mathrm{Pa}$ et $5 \mathrm{kPa}$ pour les fromages intacts. Cette valeur était 2 à 5 fois moins élevée lorsque la texture des fromages était détruite par transfert de leur emballage d'origine à la capsule de mesure.

Mots clés: Fromages frais - Texture - Pénétrométrie - Contrainte tangentielle. 


\section{Introduction}

Different instrumental methods have been used for studying rheological properties of cheese. TEMPLETON and SOMmer (1930) measured the force required to crush an inch cube of a processed cheese to one-half of its original thickness. DAvis (1937) applied the uniaxial compression and relaxation tests to determine the shear modulus, the viscosity and the relaxation time. Application of the compression/relaxation method for rheological studies of rennet cheeses was reviewed by WALSTRA and VAN VLIET (1982). This method has been used to measure the firmness of the rennet gellied milk at the cutting point (Scott Blair, 1938; Coppen, 1939; Scott Blair and Coppen, 1940, 1941), of the curd grains after cutting and cooking (SCOTT Blair and COPPEN, 1940) and of different types of cheese (SCOTT BLAIR and COPPEN, 1941; RaAdsveld and Mulder, 1949a, b ; Szabo, 1966 ; Le Bars and Bergère, 1976 ; Culioli and Sherman, 1976 ; Olkku and Sherman, 1979 ; Imoto et al., 1979 ; Dickinson and Goulding, 1980 ; Casiraghi et al., 1985 ; Mpagana and HARDY, 1986).

Emmons and Price (1959) used a Cherry-Burrel wire cutter to measure the firmness of a cottage cheese. A sliding pin consistometer was proposed by DAVEY (1986) to evaluate the hardness of cheese. MIRGORODSKY (1966) used a stretching machine to measure the cohesion force of cheese. Cone penetrometers have been used to evaluate the physical properties of processed cheeses (BoHAC, 1966 ; Thomas et al., 1970) and of an acid type cheese (BogdanovsKII et al., 1985). Extrusion methods were used to measure consistency of an acid cheese type Twarog (DANIEwski, 1972, 1973) and of a soft cheese (De Jong, 1976, 1977). Dynamic viscoelasticimetry was used to analyse the rheological properties of Gouda and Cheddar and of hard and soft processed cheeses (TANEYA et al., 1979) and acid cheese (MAhaut et al., 1986). A rotational viscosimeter was used to determine the apparent viscosity of acid cheese obtained from cow's and goat's milk (MAhaUT et al., 1982, 1986).

The consistency of acid, fresh cheeses, containing generally more moisture $(70-80 \%)$ than rennet, ripened cheeses $(35-50 \%)$, is usually much softer. It is often so soft that the fresh cheese is in a semi-liquid rather than a semi-solid form. The methods used to measure the consistency of cheese are mostly destructive, but it is often necessary to transfer the cheese from its original packing-box to a special sample container of a measuring device before doing the measurement. The transfer operation often causes more texture damage than the method used. Among different instrumental methods used to measure the consistency of different types of cheese, the cone penetrometer method seems to be suitable for shapeless, very soft, acid type cheeses as it allows to be directly used on the cheese samples in their packing-boxes as well as on the cheese samples being placed in a special instrument's cup.

The constant load penetrometric method has often been used to determine the consistency of butter, margarine or other solid fats. This subject was reviewed by WALSTRA (1981). Different consistency indexes and equations were used to express the results obtained by this method: Dixon and PArekH 
(1979) found the following empirical relation for the cone penetrometric determination of the butter yield stress :

$$
\mathrm{S}=\mathrm{m} \cdot \delta^{-1.65} \cdot \mathrm{h}^{-2}
$$

where : $\mathrm{S}=$ yield stress,

$\mathrm{m}=$ mass of the cone assembly,

$\delta=$ cone angle,

$\mathrm{h}=$ penetration depth.

The group of experts of the International Dairy Federation (WALSTRA, 1981) proposed the following equation :

$$
\mathrm{S}=\mathrm{m} \cdot \mathrm{g} /\left(\pi \cdot \mathrm{h}^{2} \cdot \tan ^{2} \delta\right)
$$

where : $\begin{aligned} \mathrm{g} & =\text { acceleration due to gravity }=9.81 \mathrm{~m} \cdot \mathrm{s}^{-2} \text {, } \\ \pi & =3.1415 \ldots\end{aligned}$

Hayakawa and Deman (1982) calculated a hardness index (H.I.) of fats as a quotient of the mass of the cone assembly $(\mathrm{m})$ and the penetration depth (h) :

$$
\text { H.I. }=\mathrm{m} / \mathrm{h}
$$

The three given examples show the important differences between the equations and indexes taken to represent the consistency of a given product. It seems to us that the tangential stress similar to the yield stress value proposed by the I.D.F. (WALSTRA, 1981) for butter could be a reasonable index for the evaluation of acid cheese consistency.

The aim of this work was to analyse the force evolution during the constant speed penetration of a cone into the acid cheese samples and to estimate the extent of the texture damage caused by the transfer of this type of cheese samples from their original packing-boxes into a special container of the penetrometer.

\section{Materials and methods}

Three types of marketed, acid cheeses were used in our studies :

1) homogenized, low solids cheese, « Calin » (Yoplait, France), having $40 \%$ fat/total solids, $19 \%$ dry matter, $6.6 \%$ proteins ;

2) medium solids cheese, «St. Céols» (Triballat, France), having $38 \%$ fat/total solids, $25.6 \%$ dry matter and $10.4 \%$ proteins ;

3) high fat, «St. Môret» (Fromarsac, France), having $54 \%$ fat/total solids, $36.6 \%$ dry matter and $10.3 \%$ proteins.

The cheese samples were purchased in a local supermarket. The dry matter, fat and protein content were determined by using standard methods.

The LFRA Texture Analyser (Stevens, Great Britain) was used as a constant speed cone penetrometer. The maximal penetration depth was set at $25 \mathrm{~mm}$. The penetration speeds were $0.2,0.5,1.0$ and $2.0 \mathrm{~mm} / \mathrm{s}$ and the cone angles were $20,30,40,60$ and $90^{\circ}$. The cones were made of polyamide in our workshop. The full scale load of the penetrometer force transducer was $1 \mathrm{~N}$. The penetrometer output signal, proportional to the force $(1.4 \mathrm{~V} / \mathrm{N})$, was 
digitalized by a digital multimeter type PM 2534 (Philips, Holland), which was connected to the microcomputer Apple II plus (Apple Computer, USA) through the interface I-EEE (Apple Computer, USA). For the data acquisition a modified programme previously described (KonolczuK et al., 1985) was used. The data acquisition speed was about 4 measurements per second for the force and for the time from Apple Clock (Mountain Computer Inc., USA). $\mathrm{Up}$ to 1500 readings of time and force were recorded in each experiment on a flexible disc type 2 Megas (Micro Expansion, France).

The cheese temperature was $18^{\circ} \mathrm{C} \pm 1{ }^{\circ} \mathrm{C}$. The penetration tests were done first in the original plastic boxes of cheese $(250 \mathrm{~g}$ for St. Môret, $500 \mathrm{~g}$ for Calin and $250 \mathrm{~g}$ pieces of St. Céols cheeses). Three penetration tests for each cheese sample were done. Two penetration tests were done each cone and each penetration speed. Another serie of tests was carried out after the cheese samples had been removed from their original boxes and transfered with a tea spoon into stainless steel containers of $62 \mathrm{~mm}$ diameter and $25 \mathrm{~mm}$ height. In this case the original consistency of the cheese was very much weakened.

\section{Calculations}

It can be assumed, basing on Newton's law, that for the cone penetration test, the tangential force $\left(F_{t}\right)$ is proportional to the apparent viscosity $\left(\eta_{\mathrm{a}}\right)$, surface of the cone being in contact with a product (A) and the rate of strain $(\dot{\gamma}):$

$$
\mathrm{F}_{\mathrm{t}}=\eta_{\mathrm{a}} \cdot \mathrm{A} \cdot \dot{\gamma}
$$

In fact, neither $\eta_{\mathrm{a}}$ nor $\dot{\gamma}$ are known, but at least the force $(F)$ and the contact surface (A) are measured with quite a good precision. This allows to calculate the tangential or shearing stress $\left(S_{t}\right)$ at the surface of the cone :

$$
\mathrm{S}_{\mathrm{t}}=\mathrm{F}_{\mathrm{t}} / \mathrm{A}=\eta_{\mathrm{a}} \cdot \dot{\gamma}
$$

So, as it was done for the constant load penetrometric test, we can take the tangential stress $\left(S_{t}\right)$ as a consistency index of a studied product. The main difference between the constant load and the constant speed tests is that in the first case the penetration speed and so the rate of strain is decreasing all the time during the test, while in the second case it is reasonably constant. The apparent viscosity of many food products depends much on the rate of strain, and this is also the case of the acid type cheese (Mahaut et al., 1982, 1986). However, for the constant penetration speed the strain rate does not vary greatly during penetration (especially for a small cone angle) and consequently the tangential stress would remain more or less constant.

As shown in fig. 1 the tangential force $\left(F_{t}\right)$ is given by :

$$
\mathrm{F}_{\mathrm{t}}=\mathrm{F} \cdot \cos \delta
$$

where : $\delta=$ half the cone angle.

The external surface (A) being in contact with a product is :

$$
\mathrm{A}=\pi \cdot \mathrm{h}^{2} \cdot \tan \delta / \cos \delta
$$



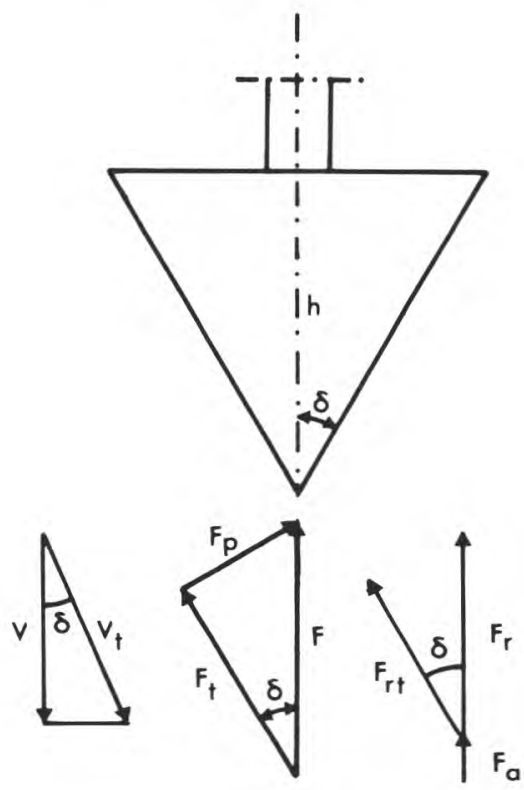

Fig. 1

Trigonometric relations between:

a) the penetration velocity $(V)$ and the tangential penetration velocity $\left(V_{t}\right)$, b) measured force $(F)$, tangential force $\left(F_{t}\right)$ and perpendicular force $\left(F_{p}\right)$, c) Archimedean force $\left(F_{a}\right)$, product reaction force $\left(F_{r}\right)$ and tangential, product reaction force $\left(F_{r t}\right)$. Other symbols: $\delta=$ half of the cone angle, $h=$ penetration depth.

Relations trigonométriques entre:

a) vitesse de pénétration $(V)$ et vitesse tangentielle de pénétration $\left(V_{t}\right)$, b) force mesurée $(F)$, force tangentielle $\left(F_{t}\right)$ et force perpendiculaire $\left.\left(F_{p}\right), c\right)$ poussée d'Archimède $\left(F_{a}\right)$, force de réaction du produit $\left(F_{r}\right)$ et force tangentielle de réaction du produit $\left(F_{r}\right)$. Autres symboles : $\delta=$ moitié de l'angle du cône, $h=$ profondeur de pénétration.

so, the tangential stress is :

$$
\mathrm{S}_{\mathrm{t}}=\mathrm{F} \cdot \cos ^{2} \delta /\left(\pi \cdot \mathrm{h}^{2} \cdot \tan \delta\right)=\mathrm{K} \cdot \mathrm{F} / \mathrm{h}^{2}
$$

where : $\mathrm{K}=\cos ^{2} \delta /(\pi \cdot \tan \delta)=$ cone constant.

The equation (8) was proposed by Rebinder and Semenenko (1949) for a constant force cone penetrometer and it is very similar to that proposed by the I.D.F. (WALSTRA, 1981) to determine the tangential stress, called also the yield stress value of a butter or a margarine.

It should be taken into account that the measured force $(F)$ is composed of two parts (fig. 1): the force representing the products's resistance $\left(F_{r}\right)$ and the buoyancy or Archimedean force $\left(F_{a}\right)$ :

$$
\mathrm{F}=\mathrm{F}_{\mathrm{r}}+\mathrm{F}_{\mathrm{a}}
$$


The latter force $\left(F_{a}\right)$ is proportional to the cone's volume $(\mathrm{V})$ being immersed into the product and to the product density (d) :

$$
F_{a}=V \cdot d \cdot g=\left(\pi \cdot h^{3} \cdot d \cdot g \cdot \tan ^{2} \delta\right) / 3
$$

since the force due to the cone weight is compensated by the instrument. The density (d) of the analysed cheese samples, calculated on the basis of their chemical composition was between 1.03 and $1.04 \mathrm{~g} / \mathrm{cm}^{3}$. For very soft cheese samples as Calin, the force $\left(\mathrm{F}_{\mathrm{a}}\right)$ represented up to $10 \%$ of the measured force (F). For other samples (St. Céols and St. Môret) it makes up only about $1 \%$ or less and practically could be neglected. In this work we have taken into account the Archimedean force $\left(F_{a}\right)$ for the calculations of the tangent stress $\left(\mathrm{S}_{\mathrm{t}}\right)$ by equation (8).

\section{Results and discussion}

Figure 2 shows the force evolution during the penetration of the cone into the cheese samples. Each of the three curves represents a different cheese sample : very soft Calin and much harder S. Céols and S. Môret. The force seems to be a parabolic function of the penetration depth as indicated by

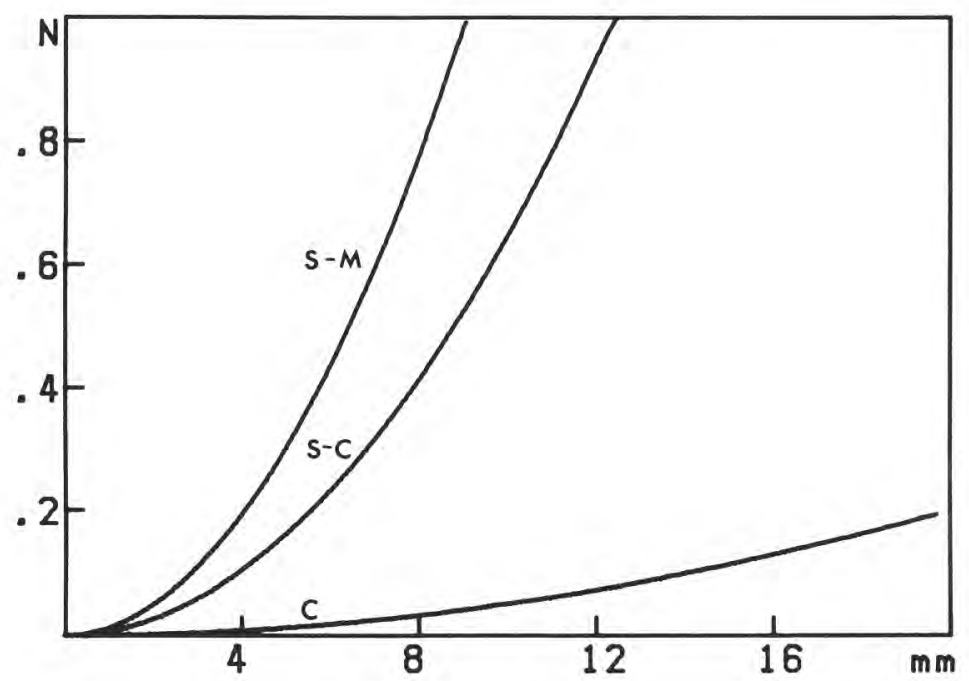

Fig. 2

Force $(N)$ evolution during the penetration of acid cheese samples as a function of the penetration depth $(\mathrm{mm})$. Cheese samples : $C=$ Calin, $S-C=$ Saint-Céols, $S-M=$ SaintMôret. Experimental conditions : cone angle $30 \mathrm{deg}$, penetration velocity $2 \mathrm{~mm} / \mathrm{s}$.

Evolution de la force $(N)$ en fonction de la profondeur de pénétration $(\mathrm{mm})$ des fromages. Echantillons de fromages : $C=$ Calin, $S$-C $=$ Saint-Céols, $S$ - $M=$ Saint-Môret . Conditions expérimentales : angle du cône $=30 \mathrm{deg}$, vitesse de pénétration $=2 \mathrm{~mm} / \mathrm{s}$. 
equation (8). In fact if the square root of the force is plotted against the penetration depth (fig. 3) then the curves become linear. The noise to signal ratio was quite high in the initial part of the curves. The noise was caused by the vibrations coming from external sources and from the stepping motor of the rheometer. The resolution of the analog to digital convertor used in this study was 12 bits i.e. $1 / 4096=.0244 \%=.244 \mathrm{mN}$. The noise coming from the external sources as well as from the rheometer was about 5-10 times more important. For further calculations we took into account only the forces levels exceeding $5 \%$ of the rheometer's full scale, i.e. between .05 and $1 \mathrm{~N}$.

The straight lines from figure 3 could be represented by the equation :

$$
\sqrt{\mathrm{F}}=\mathrm{a}+\mathrm{b} \cdot \mathrm{h}
$$

where : $\sqrt{\mathrm{F}}=$ square root of the force in $\sqrt{\mathrm{N}}$,

$\mathrm{h}=$ penetration depth in $\mathrm{mm}$,

$a=$ value of $\sqrt{\mathrm{N}}$ for $\mathrm{h}=0$,

$b=$ slope of the line, i.e. increase of $\sqrt{N}$ for unit increase of $h$.

As could be expected, for all analysed samples, the intercept (a) calculated by the least squares method was equal to zero, within the limits of the experimental error. So, equation (12) can be simplified to :

$$
\mathrm{F}=\mathrm{b}^{2} \cdot \mathrm{h}^{2}
$$

Replacing $\mathrm{F}$ in the equation (8) by right side of the equation (12) gives :

$$
\mathrm{S}_{\mathrm{t}}=\mathrm{K} \cdot \mathrm{b}^{2}
$$

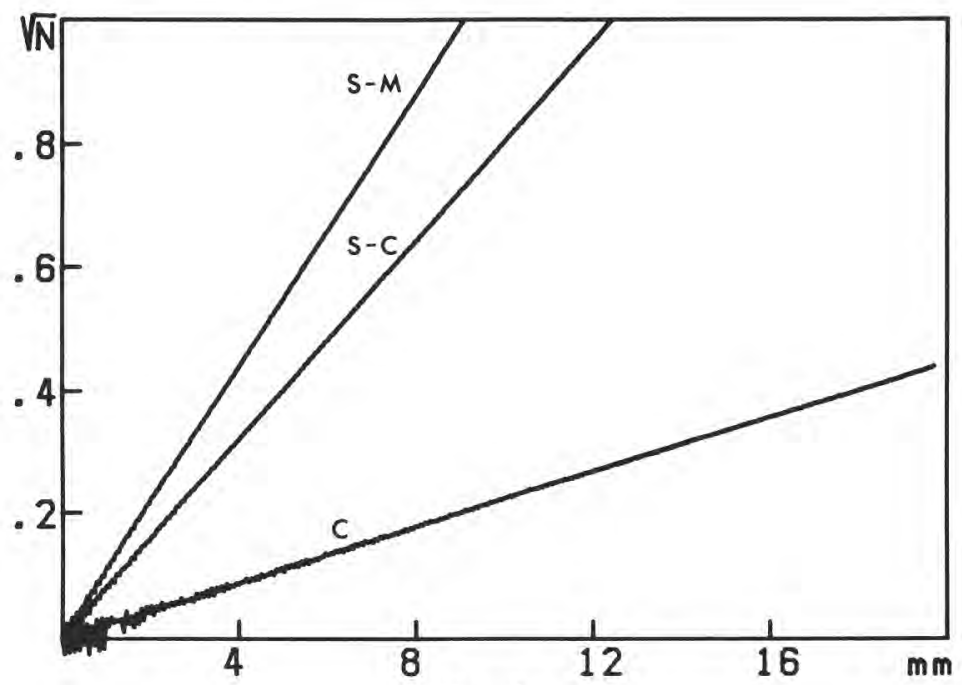

Fig. 3

Relation between the square root of the measured force $(N)$ and the penetration depth (mm) for the three types of acid cheese. Experimental conditions were the same as in fig. 2.

Corrélation entre la racine carrée de la force mesurée $(N)$ et la profondeur de pénétration $(\mathrm{mm})$ pour les trois types de fromages frais acides. Les conditions expérimentales étaient identiques à celles de la figure 2. 
The tangent stress $\left(\mathrm{S}_{t}\right)$ calculated by the equation (8) for each reading of the force and the penetration depth (fig. 4) was approximately constant, if disaccounting the scatter of the results caused by vibrations. For forces over $0.05 \mathrm{~N}$ the average value of the stress was constant and the coefficient of variation was below $2 \%$ for one penetration of a sample. For different penetrations of the same sample the coefficient of variation was below $8 \%$. EMmons and PRICE (1959), using a wire cutter for cottage cheese, found the coefficient of variation to be between $4 \%$ and $8 \%$. DickINSON and Goulding (1980), using the compression method for English cheeses, had stress variations for one sample between $15 \%$ and $18 \%$. For the quadruplicate readings of the hardness of Cheddar cheese samples by a sliding pin consistometer, the coefficient of variation was between $4 \%$ and $8 \%$ (DAVEY, 1986). For all analysed samples in this work, the tangential stresses calculated by equations (8) and (13) were equal within the limit of the experimental error.

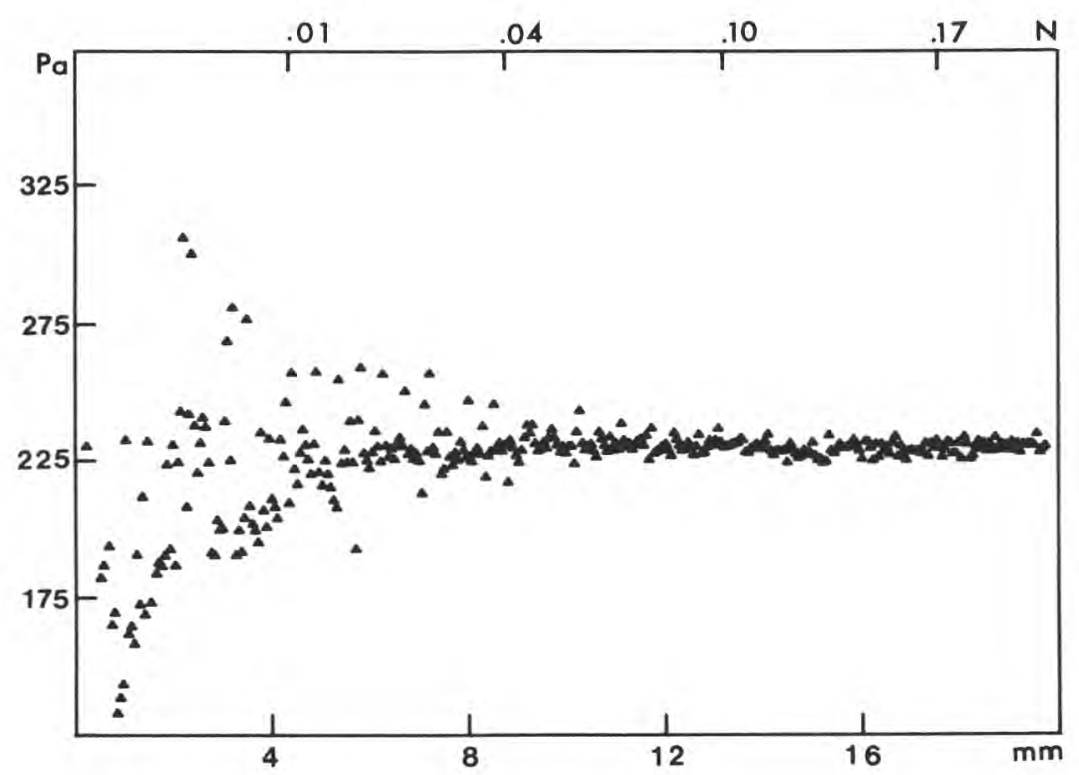

Fig. 4

Tangential stress ( $\mathrm{Pa}$ ) calculated by equation (8) as a function of the penetration depth $(\mathrm{mm})$ or measured force $(N)$. Experimental conditions : Calin cheese, cone angle $30 \mathrm{deg}$, penetration velocity $2 \mathrm{~mm} / \mathrm{s}$.

Contrainte tangentielle (Pa) calculée par l'équation (8) en fonction de la profondeur de pénétration $(\mathrm{mm})$ ou de la force mesurée $(N)$. Conditions expérimentales: fromage Calin, angle du cône $=30 \mathrm{deg}$, vitesse de pénétration $=2 \mathrm{~mm} / \mathrm{s}$.

The tangential stress was slightly increasing with increasing penetration speed and cone angle (fig. 5 and 6). For the samples of very soft cheese as Calin, the tangential stress extrapolated to a penetration speed equal to zero $\left(\mathrm{S}_{\mathrm{o}}\right)$ was about $200 \mathrm{~Pa}$, if the penetration tests were done on the undamaged 


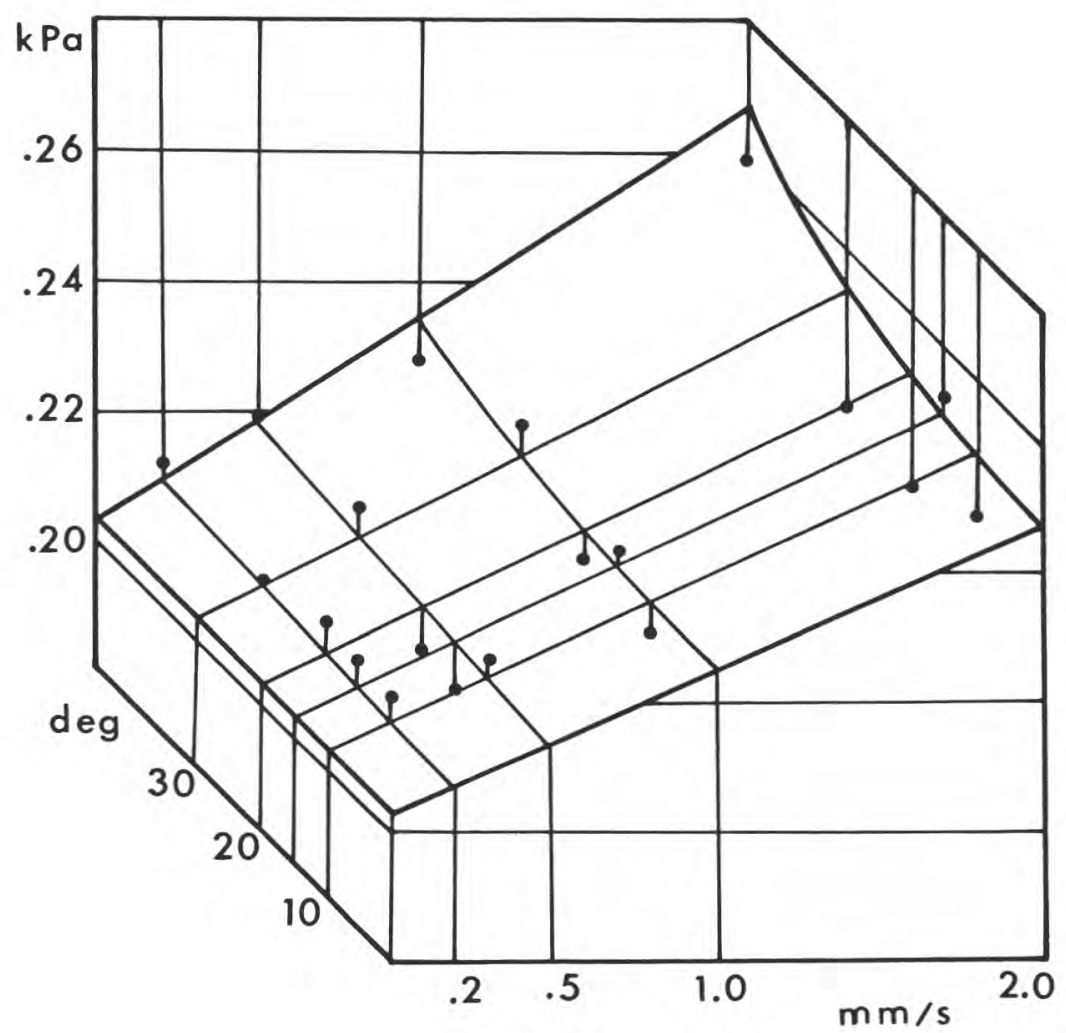

Fig. 5

Tangential stress $(\mathrm{kPa})$ for the Calin cheese, measured on the intact cheese sample, as a function of the penetration velocity $(\mathrm{mm} / \mathrm{s})$ and of the cone angle (deg).

Contrainte tangentielle $(k P a) d u$ fromage Calin, mesurée sur les échantillons de fromages intacts, en fonction de la vitesse de pénétration $(\mathrm{mm} / \mathrm{s})$ et de l'angle du cône (deg).

cheese samples (fig. 5). When the cheese samples were transfered into a special stainless steel container prior to penetration tests, the tangential stress $\left(\mathrm{S}_{\mathrm{o}}\right)$ dropped to about $80 \mathrm{~Pa}$ (fig. 6). The transfer operation caused an important change of the cheese texture and this operation should be avoided; this means that for texture measurements, cheese has to be poured in adequate containers as soon as it is made.

The studied samples of cheese, within the limits of the penetration speeds applied, behaved like Bingham body (fig. 7), i.e. the tangential stress $\left(\mathrm{S}_{\mathrm{t}}\right)$ was a linear fonction of the tangent penetration velocity $\left(V_{t}\right)$ :

$$
\mathrm{S}_{\mathrm{t}}=\mathrm{S}_{\mathrm{o}}+\mathrm{B} \cdot \mathrm{V}_{\mathrm{t}}
$$

where : $S_{o}=$ hypothetical value of the tangential stress $\left(S_{t}\right)$ for $V_{t}=0$ and

$$
\mathrm{V}_{\mathrm{t}}=\mathrm{V} / \cos \delta
$$

where : $\mathrm{V}=$ penetration velocity in $\mathrm{mm} / \mathrm{s}$. 


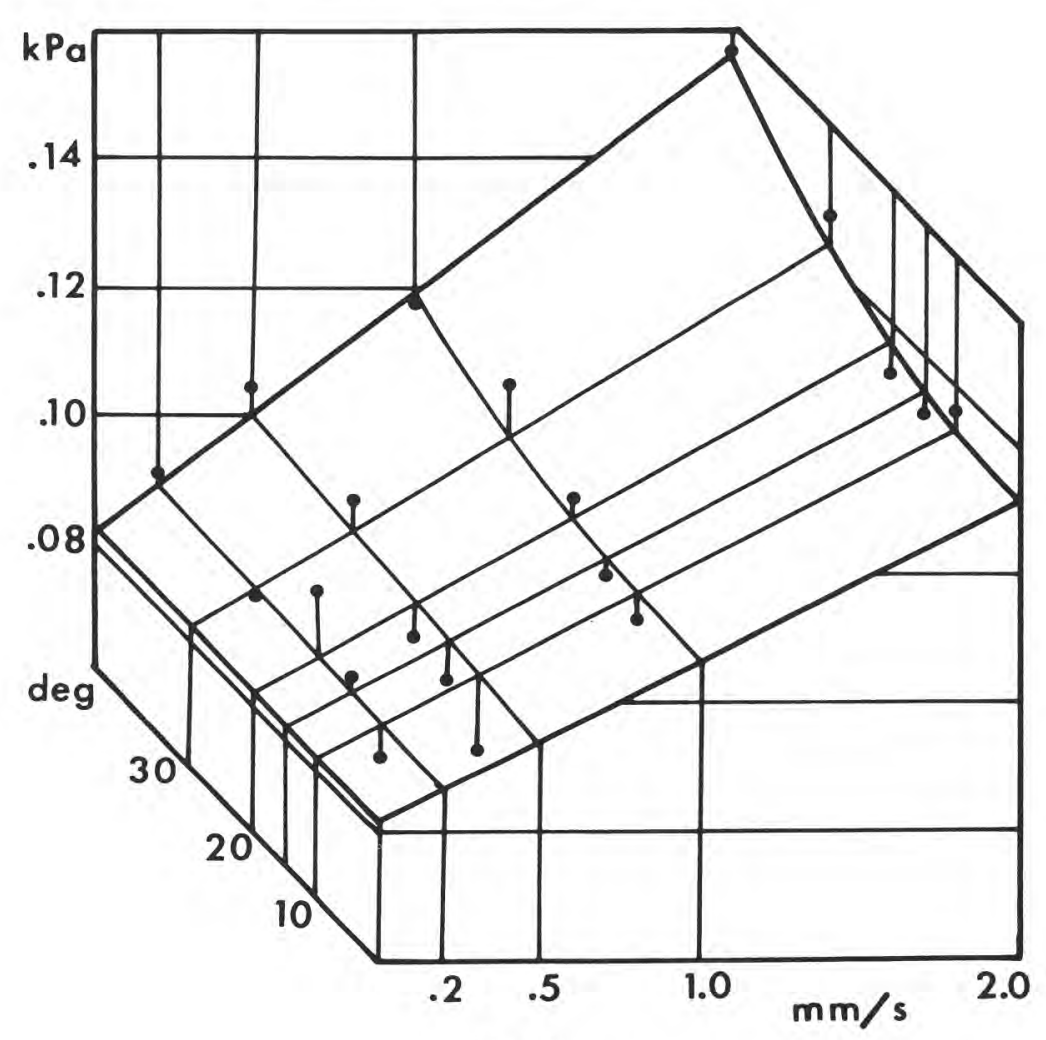

Fig. 6

Tangential stress $(\mathrm{kPa})$ of the Calin cheese, measured on the sample transfered from the packing-box into the penetrometer cup, as a function of the penetration velocity $(\mathrm{mm} / \mathrm{s})$ and of the cone angle (deg).

Contrainte tangentielle $(\mathrm{kPa})$ du fromage Calin, mesurée sur les échantillons transférés de leurs emballages d'origine à la capsule de mesure, en fonction de la vitesse de pénétration $(\mathrm{mm} / \mathrm{s})$ et de l'angle du cône (deg).

The tangential stress $\left(\mathrm{S}_{\mathrm{t}}\right)$ is thus :

$$
\mathrm{S}_{\mathrm{t}}=\mathrm{S}_{\mathrm{o}}+\mathrm{B} \cdot \mathrm{V} / \cos \delta
$$

Of course, this representation is only an approximation, based on the limited range of the penetration speeds. Undoubtedly for lower cone velocities the Bingham law would not be obeyed (MAHAUT et al., 1982, 1986).

The values of $\left(\mathrm{S}_{0}\right)$ and $(\mathrm{B})$ for the three types of cheese studied in this work are given in table 1. As may be expected (Scott Blair and Coppen, 1940, 1941; EMmons and Price, 1959 ; DANIEWSKI, 1972 ; Chen et al., 1979) the coefficient $S_{0}$ increased very much with increasing of protein and fat content. On the other hand, the higher $S_{0}$ level of the intact cheese, the more important its decrease caused by the mechanical change of the cheese texture. 


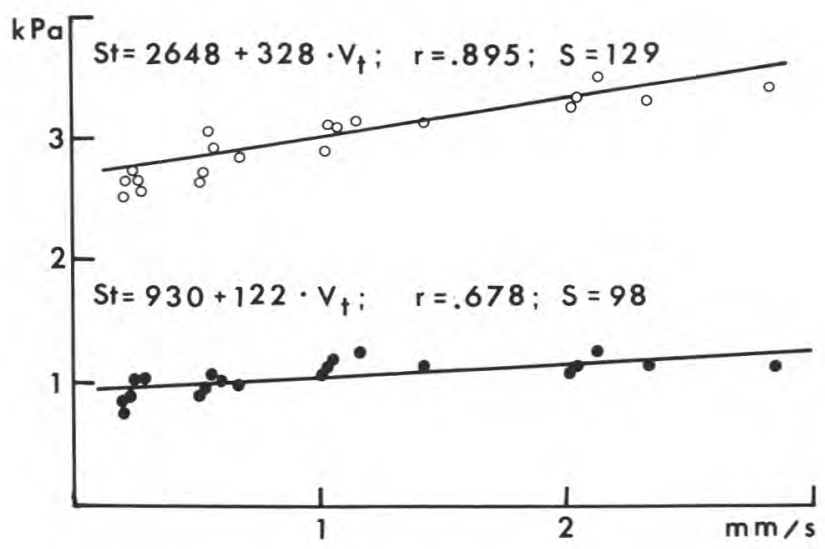

Fig. 7

Correlation between the tangential stress $(\mathrm{kPa})$ and the tangential penetration velocity $(\mathrm{mm} / \mathrm{s})$ of the St.-Céols cheese measured on the intact cheese samples in their packing-

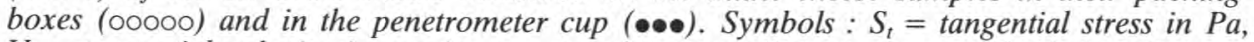
$V_{t}=$ tangential velocity in $\mathrm{mm} / \mathrm{s}, r=$ correlation coefficient, $S=$ standard deviation.

Corrélation entre la contrainte tangentielle $(\mathrm{kPa})$ et la vitesse tangentielle de pénétration $(\mathrm{mm} / \mathrm{s})$ du fromage St. Céols, mesurée sur les échantillons de fromages intacts dans

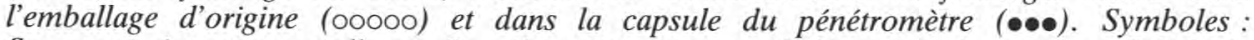
$S_{t}=$ contrainte tangentielle en $\mathrm{Pa}, V_{t}=$ vitesse tangentielle en $\mathrm{mm} / \mathrm{s}, r=$ coefficient de corrélation, $S=$ écart-type.

TABLE 1

Coefficients $S_{o}$ and $B$ from the equation (14) and their standard deviations for three types of fresh cheese

Coefficients $S_{o}$ et $B$ de l'équation (14) et leurs écarts-types pour les trois types de fromages frais

\begin{tabular}{l|c|c|c|r}
\hline \multirow{2}{*}{ Cheese } & \multicolumn{2}{|c|}{ Intact } & \multicolumn{1}{c}{ Destructured } \\
\cline { 2 - 5 } & $\mathrm{S}_{\mathrm{o}}$ & $\mathrm{B}$ & \multicolumn{1}{c}{$\mathrm{S}_{\mathrm{o}}$} & \multicolumn{1}{c}{$\mathrm{B}$} \\
\hline Calin & $204 \pm 3.6$ & $22 \pm 5.4$ & $81 \pm 7.0$ & $26 \pm 4.6$ \\
Saint-Céols & $2648 \pm 168$ & $328 \pm 18$ & $930 \pm 63$ & $122 \pm 7.1$ \\
Saint-Môret & $5008 \pm 303$ & $436 \pm 21$ & $1021 \pm 75$ & $-68 \pm 5.4$ \\
\hline
\end{tabular}

The coefficient $\mathrm{B}$ was roughly $10 \%$ of the coefficient $\mathrm{S}_{0}$ for the intact cheese samples. After mechanical treatment of the samples the coefficient B remained at about the same level for low total solids cheese (Calin), decreased markedly for medium structured (St. Céols), to become even negative for much more structured cheese (St. Môret). 
Basing on the results obtained in this work, it may be concluded that a constant speed cone penetrometer can be used to study the texture of acid type cheeses. The tangential stress determined by this method seems to be a good indicator of the consistency of cheese and it could serve to evaluate the influence of the chemical composition and technological treatments during preparation of the cheese samples. However, it has to be stressed that this is only an empirical method and it would need to be compared with methods in which well defined rheological properties can be measured.

Reçu le 7 septembre 1987.

Accepté pour publication le 15 janvier 1988.

\section{References}

Bogdanovskil V.B., Fridenberg G.V., Gorbatov A.V., Karslyants A.P., Zimin A.F., Kosol V.D., 1985. Preparation of tvarog for manufacture of speciality tvarog products under conditions of transport under pressure. Molochnaya Prom-st. (5), 25-27. Cit. after Dairy Sci. Abstr., 48 (1986), (10), 656, $\mathrm{n}^{\circ} 5536$.

BонаC V., 1966. Uber das Messen von physicalischen Werten bei der Schmelzkaseerzeugung. XVII Int. Dairy Congr. D, 263-266.

Casiraghi E.M., Bagley E.B., Christianson D.D., 1985. Behaviour of Mozzarella, Cheddar and processed cheese spread in lubricated and bonded uniaxial compression. J. Texture Stud., 16, 281-301.

Chen A.H., Larkin J.W., Clark C.J., Irwin W.E., 1979. Textural analysis of cheese. J. Dairy Sci., 62, 901-907.

Coppen F.M.V., 1939. The assessment of curd firmness prior to cutting. J. Dairy Res., 10, 336339.

Culoli J., Sherman P., 1976. Evaluation of Gouda cheese firmness by compression tests. J. Texture Stud., 7, 353-372.

DanIEWSKı P., 1972. Determination of consistency of skim-milk acid twarog by the shear method. Rocz. Inst. Przem. Mlecz., 14 (3), 43-48.

Daniewski P., 1973. Effect of processing conditions on consistency of low-fat twarog. Rocz. Inst. Przem. Mlecz., 15 (2), 107-115.

DAVEY K.R., 1986. Measurement of the hardness and mouthfeel of cheese using a sliding pin consistometer. J. Texture Stud., 17, 267-274.

Davis J.G., 1937. The rheology of cheese, butter and other milk products. J. Dairy Res., 8, 245264.

De Jong L., 1976. Protein breakdown in soft cheese and its relation to consistency. 1. Proteolysis and consistency of Noorhollandse Meshanger cheese. Neth. Milk Dairy J., 30, 242-253.

DE Jong L., 1977. Protein breakdown in soft cheese and its relation to consistency. 2. The influence of rennet concentration. Neth. Milk Dairy J., 31, 314-327.

Dickinson E., Goulding I.C., 1980. Yield behaviour of crumbly English cheeses in compression. J. Texture Stud., 11, 51-63.

Dixon B.D., PAREkh J.V, 1979. Use of the cone penetrometer for testing the firmness of butter. J. Texture Stud., 10, 421-434.

Emmons D.B., Price W.V., 1959. A curd firmness test for cottage cheese. J. Dairy Sci., 42, 553556.

Hayakawa M., Deman J.M., 1982. Interpretation of cone penetrometer consistency measurements of fats. J. Texture Stud., 13, 201-210. 
Imoto E.M., LeE C., Rha C., 1979. Effect of compression ratio on the mechanical properties of cheese. J. Food. Sci., 44, 343-345.

Korolczuk J., Roignant M., Maubois J.-L., 1985. Computer data acquisition of sinusoidally varying stress and strain. J. Texture Stud., 16, 129-142.

LE BARS, D. Bergère J.-L., 1976. Mesure de la texture des fromages à l'aide d'un appareil simple. Lait, 56 (558), 485-494.

Mahaut M., Korolczuk J., Pannetier R., Maubois J.-L., 1986. Eléments de fabrication de fromage de type pâte molle de lait de chèvre à caractère lactique par ultrafiltration de lait acidifié et coagulé. Tech. Lait., Market., (1011), 24-28.

Mahaut M., Maubois J.-L., Zink A., Pannetier R., Veyre R., 1982. Eléments de fabrication de fromages frais par ultrafiltration sur membrane de coagulum de lait. Tech. Lait., (961), 9- 13.

Mirgorodsky B., 1966. Method for determination of the cohesion of cheese grains in monolith. XVII Int. Dairy Congr. D, 421-424.

Mpagana M., Hardy J., 1986. Effect of salting on some rheological properties of fresh Camembert cheese as measured by uniaxial compression. Milchwissenschaft, 41, 210-213.

OlKKu J.E., Sherman P., 1979. Compression testing of cylindrical samples with an INSTRON universal testing machine. In : Food Texture and Rheology. Ed. Sherman P., Academic Press, London, New York, San Francisco, 157-175.

RaAdsveld C.W., Mulder H., 1949a. The influence of the temperature on the ripening of edam cheese. Neth. Milk Dairy J., 3, 117-141.

RaAdsveld C.W., Mulder H., 1949b. The influence of $\mathrm{pH}$ on the ripening of edam cheese. Neth. Milk Dairy J., 3, 222-230.

Rebinder P.A., Semenenko N.A., 1949. Use of the penetrating cone method for the characterization of structural-mechanical properties of viscoplastic material. Proc, Acad. Sci. U.S.S.R., 64. 835-838. Cit. after Dixon and Parekh (1979).

SCOTT Blair G.W., 1938. An apparatus for measuring the elastic and plastic properties of cheese curd. J. Dairy Res., 9, 347-350.

SCott Blair G.W., Coppen F.M.V., 1940. An objective measure of the consistency of cheese curd at the pitching point. J. Dairy Res., 11, 187-195.

Scott Blair G.W., Coppen F.M.V., 1941. The consistency of cheese curd at the pitching point and its bearing on the firmness and quality of the finished cheese. J. Dairy Res.. 12, 44-54.

Szaвo G., 1966. Uber dir rheologischen Eigenschaften des Scmelzkases. XVII Int. Dairy Congr. D, 257-262.

TANeya S., Izutsu T., Sone T., 1979. Dynamic viscoelasticity of natural cheese and processed cheese. In : Food Texture and Rheology. Ed. by Sherman P., Academic Press. London, New York, San Francisco, 369-383.

Templeton H.L., Sommer H.H., 1930. Some observations on processed cheese. J. Dairy Sci., 13. 203-219.

Thomas M.A., Brown F.B., Hanly A.T., 1970. Studies in processed cheese manufacture - the evaluation of physical properties. Aust. J. Dairy Technol., 25, 46-51.

Walstra P., 1981. Evaluation of the firmness of butter. FIL/IDF Bulletin. Document 135, 1-11.

Walstra P., Van Vliet T., 1982. Rheology of cheese. In IDF Annual Sessions 1981 (Technology, Science and Nutrition). FIL-IDF. Document 153, 22-27. 